\title{
POŠTA
}

TELEKOMUNIKÁCIE A

ELEKTRONICKY OBCHOD

Qlelentoming

=

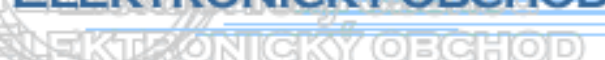

\section{STAV E-GOVERNMENTU VO VYBRANÝCH KRAJINÁCH EÚ}

\author{
Margita Majerčáková*
}

\section{Úvod}

Úroveň elektronických služieb verejnej správy v SR bola na konci predošlého roka pre občanov na vel'mi nízkej úrovni. Vyplynulo to zo zistení mimovládneho Inštitútu pre verejné otázky (IVO). V prípade elektronických služieb pre občanov dosiahli referenčné hodnoty stanovené Európskou komisiou iba dve z celkovo dvanástich sledovaných služieb. Jedným z vysvetlení takéhoto stavu je fakt, že občania nemajú dostatočnú silu (na rozdiel napr. od podnikatel'ského sektora), aby vyvinuli efektívny tlak na ich zavádzanie. Problém občanov spočíva aj v tom, že bežní l'udia nedokážu presnejšie definovat' svoje požiadavky a na základe toho nedokážu ,generovat"“ väčší dopyt po elektronických službách.

\section{Porovnanie e-governmentu za rok 2007}

Porovnávanie e-Governmentu v krajinách EÚ je vykonané na základe dokumentu Benchmarking The Supply Of Online Public Services 2007 [1]. Tento dokument je výsledkom siedmeho merania progresu vo verejných online službách.

V tomto porovnaní pre rok 2007 sú ako základné indikátory merania a porovnávania:

- online sofistikovaný indikátor založený na novom pät' stupňovom modeli,

- indikátor počtu verejných služieb ktoré sú plne dostupne online, dostupné $24 \mathrm{~h}$ denne meraný prostredníctvom existujúceho štvorstupňového modelu,

- hodnotenie národných portálov.

Porovnanie je založené v prvom rade na klasickom web-založenom hodnotení viac ako 5000 verejných agentúr a 14000 webových stránok poskytujúcich dvadsat' verejných služieb v 31 zúčastnených krajinách. Krajiny, ktoré sa zúčastnili tohto porovnania sú 27 členských krajín EÚ, Nórsko, Švajčiarsko, Island a Turecko. Tieto zúčastnené krajiny nazveme spoločne EU27+.

\section{Verejné služby dostupné online}

Pri porovnávaní e-Governmentov krajín EU27+ sa vychádza z porovnávanie 20 služieb, ktoré majú byt' dostupné občanom a podnikatel'om nepretržite online.

\section{Vláda a občan}

- Daň z príjmov fyzickej osoby - občan

- Evidencia vozidiel

- Osobne doklady

- Oznámenia polícii

- Oznámenie o prest'ahovaní

\footnotetext{
* Dr. Ing. Margita Majerčáková, Katedra spojov, Fakulta prevádzky a ekonomiky dopravy a spojov, Žilinská univerzita v Žiline, Univerzitná 1, 01026 Žilina, Slovenská republika, tel.: +421415133126, fax:

+421415655615 e-mail: Margita.Majercakova@fpedas.uniza.sk
} 
- Prihlásenie na vysoké školy

- Príspevky soc. Zabezpečenia

- Stavebne povolenia

- Úradné výpisy z matriky

- Verejne knižnice

- Vyhladávanie pracovného miesta

- Služby zdravotníctva

2. Vláda a podnikatel'

- Colne vyhlásenia

- Daň z pridanej hodnoty

- Daň z príjmov fyzickej osoby (podnikatel') /právnickej osoby

- Povolenia životného prostredia

- Registrácia právnickej osoby

- Sociálne dávky pre zamestnancov

- Verejne obstarávanie

- Vykazovanie štatistických údajov

\section{Online sofistikácia a plná online dostupnost' služieb}

Pre meranie indikátora dostupnosti online verejných služieb bol vytvorený model esofistikácie. Tento model ilustruje rôzne stupne sofistikácie online verejných služieb a to od základných služieb, cez jednosmernú a obojsmernú interakciu až po plné elektronické riešenie prípadov.

\section{Úroveň online služieb}

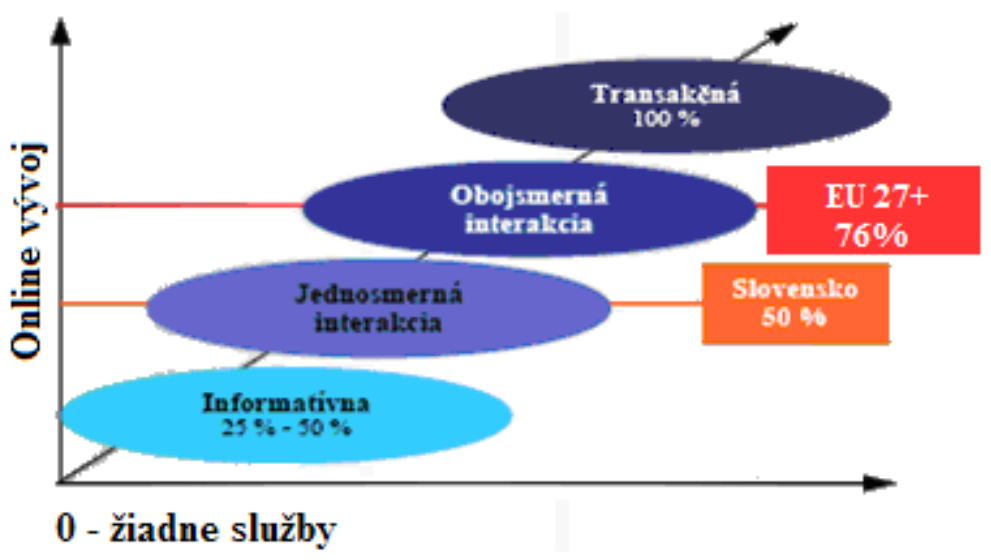

Obr. 1. Úroveň online služieb e-Governmentu EU 27 a Slovenska [2]

Čiastočná online dostupnost' služieb - má stupne 0 až 3. Plná online dostupnost' služieb zaručuje, že všetky dostupné služby sú nad tretím stupňom v sieti sofistikácie.

0 . Poskytovatel' služby je bez on-line pripojenia, nemá verejne prístupnú internetovú stránku alebo na verejne prístupnej internetovej stránke poskytovatela sa nenachádzajú informácie potrebné na začatie poskytovania príslušnej verejnej služby. Občan/podnikatel' realizuje vybavenie príslušnej služby „papierovým“ spôsobom.

1. Informatívna - Na verejne prístupnej internetovej stránke sú dostupné informácie pre klienta, napríklad kontakt (poštová alebo elektronická adresa inštitúcie poskytujúcej danú službu, prípadne mená konkrétnych pracovníkov), úradné hodiny, dokumenty a d'alšie náležitosti, ktoré sú potrebné na začatie administratívneho spracovania príslušnej verejnej služby. 
2. Jednosmerná interakcia - Z verejne prístupnej internetovej stránky si môže klient stiahnut' tlačivá, formuláre alebo iné dokumenty potrebné na začatie administratívneho spracovania príslušnej verejnej služby. Stiahnuté príslušné tlačivá klient vyplní, zabezpečí k nim prílohy a po skompletizovaní ich zašle alebo osobne doručí príslušnému spracovatel'ovi služby. Spracované rozhodnutie si vyzdvihne osobne alebo poštou.

3. Obojsmerná interakcia - Pomocou verejne prístupnej internetovej stránky je možná vzájomná komunikácia (interakcia) medzi poskytovatel'om na jednej strane a klientom na druhej strane. Znamená to, že klient môže nielen získat' tlačivá potrebné na využitie príslušnej verejnej služby, ale prostredníctvom tej istej verejne prístupnej internetovej stránky môže tieto vyplnené tlačivá aj spätne odoslat'. Táto forma si vyžaduje autentifikáciu klienta, aby sa príslušná verejná služba zrealizovala. Klient už nemusí vyplnené dokumenty a príslušné prílohy zasielat' alebo osobne doručit' príslušnému poskytovatel'ovi. V priebehu spracúvania služby sa klient informuje o stave spracovania. Spracované rozhodnutie si vyzdvihne osobne alebo poštou.

4. Transakčná - Na verejne prístupnej internetovej stránke má klient možnost' kompletne elektronicky spracovat' príslušnú službu (vrátane sledovania prijatia rozhodnutia a uskutočnenia finančnej transakcie). Poskytovaná služba sa realizuje bez priameho kontaktu klienta. Nahradzuje osobný alebo poštový kontakt medzi poskytovatel'om a klientom. Takéto spracovanie príslušnej služby si nevyžaduje d’alšie administratívne ,papierové“ konanie[2].

Existujúci rámec bol rozšírený aby sa zahrnul piaty stupeň sofistikácie založený na personalizácií. Rámcové meranie pre rok 2007 zahŕňa nasledovné indikátory:

- nezmenený indikátor na počet verejných služieb plne online dostupných, kde plne online dostupné služby sú merané pôvodným štvorstupňovým modelom,

- online sofistikačný ukazovatel' založený na novom, pät' stupňovom modeli.

Nový pät' stupňový model sofistikácie uvádza dva nové koncepty:

- myšlienku pro-aktívneho poskytovanie služieb. Vláda pro-aktívne vykonáva činnosti na rozšírenie kvality poskytovaných služieb a user friendly prístupu. (Príklad pre pro-aktivitu je: verejná správa vyplní niektoré údaje v aplikačnom formulári, ktoré sú už obsiahnuté v databáze verejnej správy),

- myšlienka automatického doručovania/poskytovania služieb, kde verejná správa automaticky poskytuje špecifické služby to znamená, sociálne a ekonomické práva pre užívatel'a a spoločnosti, spojene s určitou podmienkou užívatel'a.

\section{Hodnotenie sofistikácie v krajinách EU27+}

Európa dosiahla celkovú sofistikáciu na úrovni medzi "obojsmernou interakciou“ a "plnohodnotnými elektronickými transakciami“, vyjadrením v percentách úroveň 76\% (Obr. 1.).

$\mathrm{Na}$ porovnanie, $\mathrm{v}$ roku 2006, s ktorým bolo porovnanie vykonané sa sofistikácia nachádzala na úrovni obojsmernej interakcie. Za pozornost' stojí fakt, že sofistikovanost' stúpa so vstupom nových členov do EÚ a do tohto hodnotenia bolo započítané aj Turecko.

Zaujímavý je rozdiel $\mathrm{v}$ hodnotách medzi sofistikáciou služieb pre občanov a pre podnikatel’ov pre jednotlivé krajiny. Z porovnaní vyplýva že, sofistikácia služieb pre občanov dosiahla priemer $70 \%$ a verejné služby pre podnikatel'ov dosiahli priemer $84 \%$ pre EU27+ (Obr.2.,3.) 


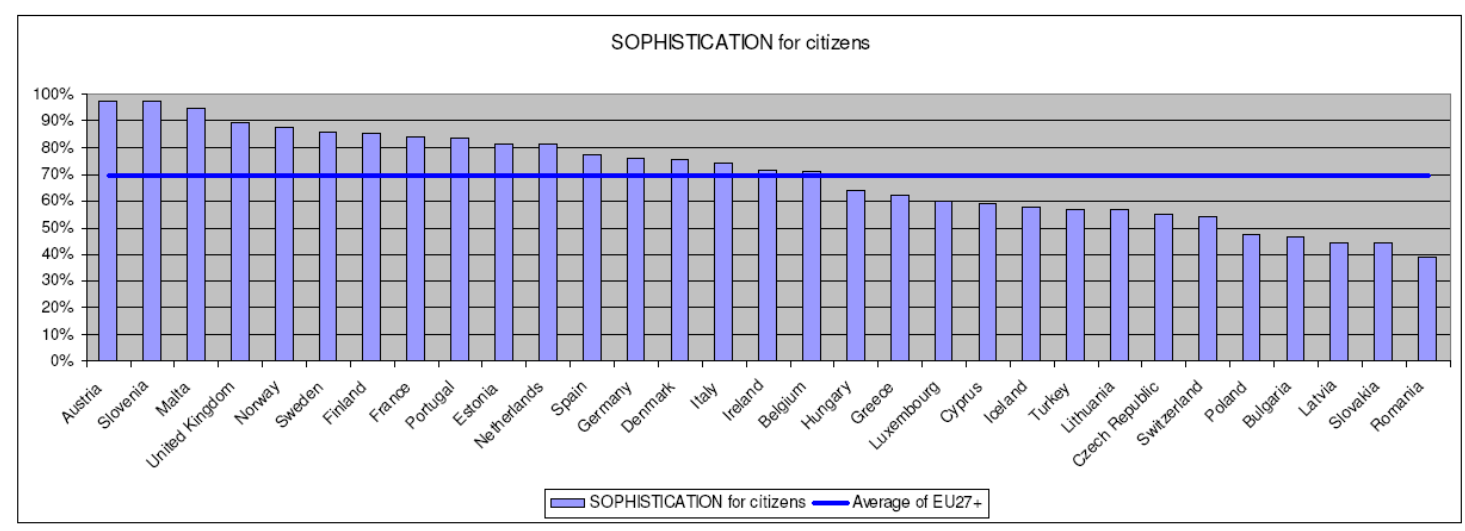

Obr. 2. Sofistikácia služieb pre občanov [1]

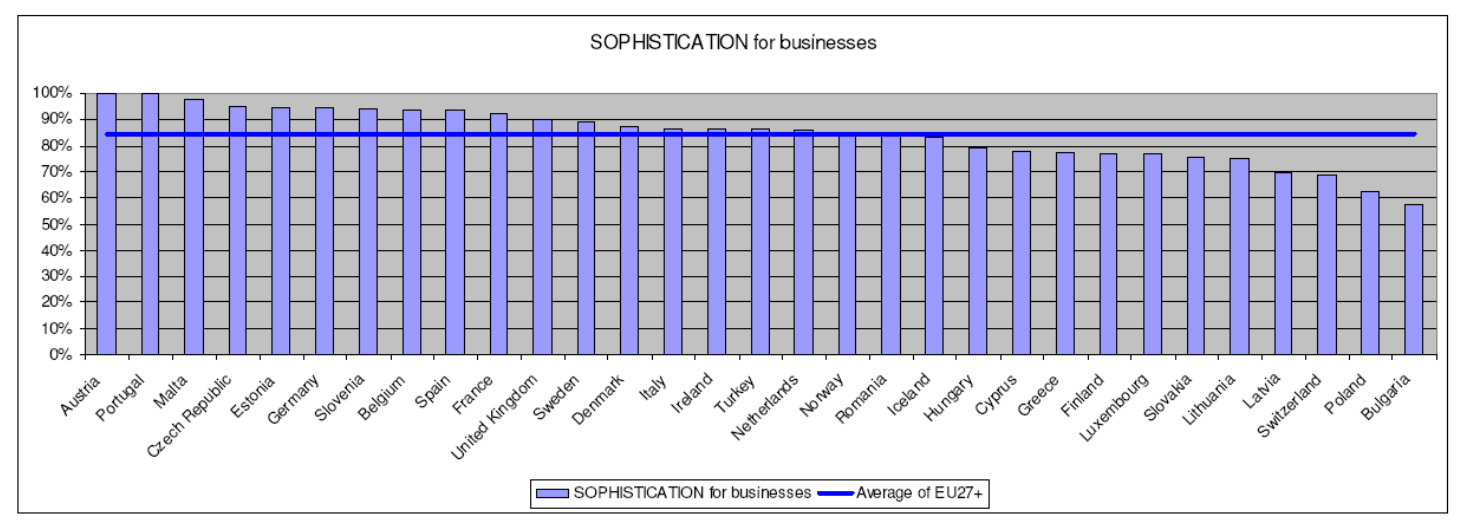

Obr. 3. Sofistikácia služieb pre podnikatel'ov [1]

\section{Hodnotenie online dostupnosti služieb EU27+}

Nárast nepretržitej online dostupnosti služieb v EU27+ znázorňuje Obr. 4. V priemere pre občanov a podnikatel'ov táto hodnota vzrástla z 50\% v roku 2006 na 58\% v roku 2007.

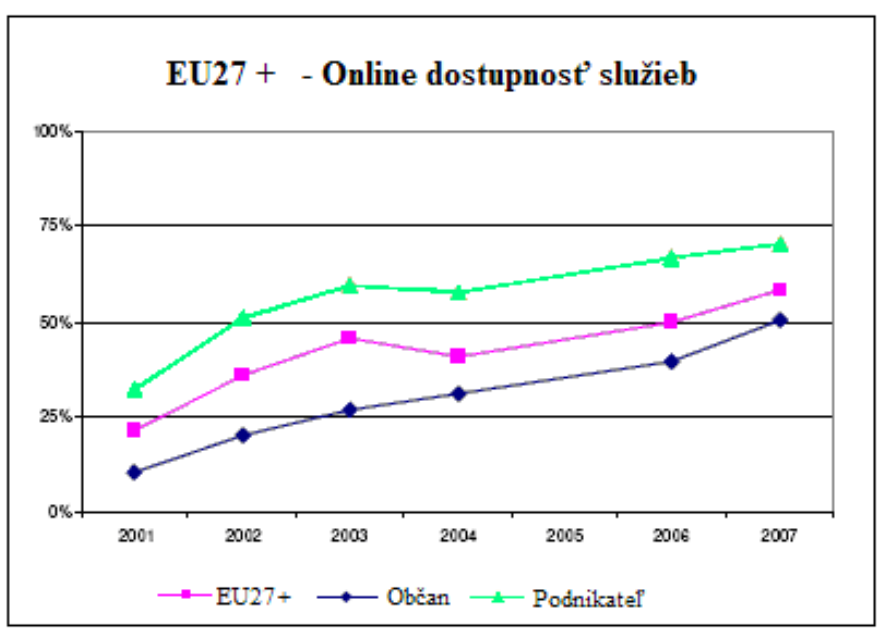

Obr. 4. Online dostupnost' služieb v EU27+ [1]

\section{Hodnotenie národných portálov EU27+}

Národný portál ponúka prístup k rôznym druhom služieb. V rámci jedného portálu tak centralizuje rôzne služby verejnej správy, ktoré sú dostupné na jednotlivých stránkach daných úradov. Dosiahnutie lepších skúsenosti pre užívatel'ov je možné cez prístup, "pozriem a vidím“ na všetkých web stránkach verejnej správy umožňujúci rýchlu a jednoduchú orientáciu 
užívatel'a. Ďalej použitie integrovaného manažmentového systému, ktorý bude zobrazovat' služby podl'a osobných preferencií, prezentačný mód a d'alšie služby.

Aby sa dosiahlo hodnoverné a objektívne hodnotenie kvality národných portálov dôraz sa kladie na:

- vízie zoskupenia služieb a zlepšovanie ich dostupnosti, prístupu a použitia,

- osobnú skúsenost' užívatel'ov,

- hodnotenie rozsahu back-office, ktorý bol integrovaný cez vládny orgán.

Hlavou otázkou výskumu zostáva, ktoré z dvadsiatich základných služieb pre verejnost' sú dostupné prostredníctvom národného portálu.

S výsledným priemerom $75 \%$ pre EU27+ je možné povedat', že vlády investovali do ich národných portálov a tieto sa stávajú skutočnými vstupnými bránami poskytovania služieb verejnej správy. Ďalším dôležitým ukazovatel’om je skutočnost', že z dvadsiatich základných služieb verejnej správy je až $73 \%$ dostupných prostredníctvom týchto portálov.

\section{Hodnotenie pro-aktívnych služieb}

Pro-aktívna personalizácia má vel'a spoločného s užívatel'skou súmernost'ou, inými slovami, spôsobom akým sú služby organizovane podl'a potrieb občanov.

Medzi tieto služby patria:

- daň z príjmov,

- verejné knižnice,

- vykazovanie štatistických údajov,

- povolenia životného prostredia,

- cestovné doklady,

- vodičské oprávnenia,

- študentské granty,

- liečebné náklady,

- príspevky na diet'a.

Výsledkom zist'ovania je, že v priemere je dostupných až 36\% pro aktívnych služieb. Najvyššiu percentuálnu hodnotu dosahuje Slovinsko, ktoré má až $80 \%$ pro-aktívnych služieb dostupných online (Obr. 5.).

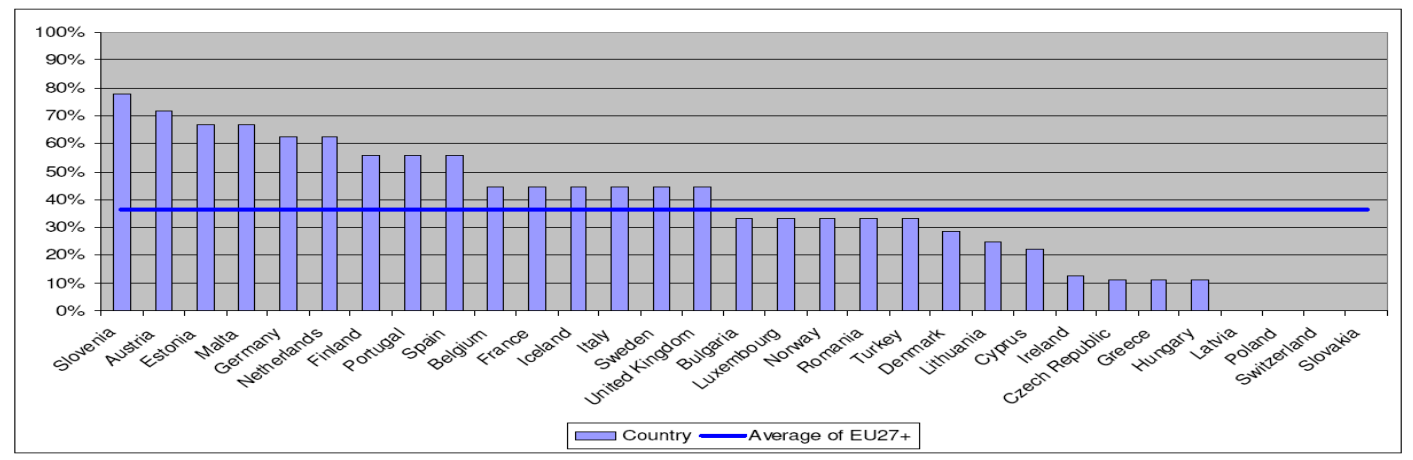

Obr. 5. Hodnotenie online dostupnosti pro-aktívnych služieb [1]

\section{Porovnávanie e-Governmentu vybraných krajín EÚ}

Slovenská republika je najčastejšie konfrontovaná a porovnávaná s krajinami V4, ked’že sa jedná o najbližších susedov. Porovnávame teda e-Government Slovenska, Pol'ska, Mad'arska, Českej republiky a Slovinska. Slovinsko z dôvodu, že vstúpila medzi prvými krajinami, ktoré sa v 1. mája 2004 pripojili k EÚ do menovej únie.

\section{Slovenská republika}



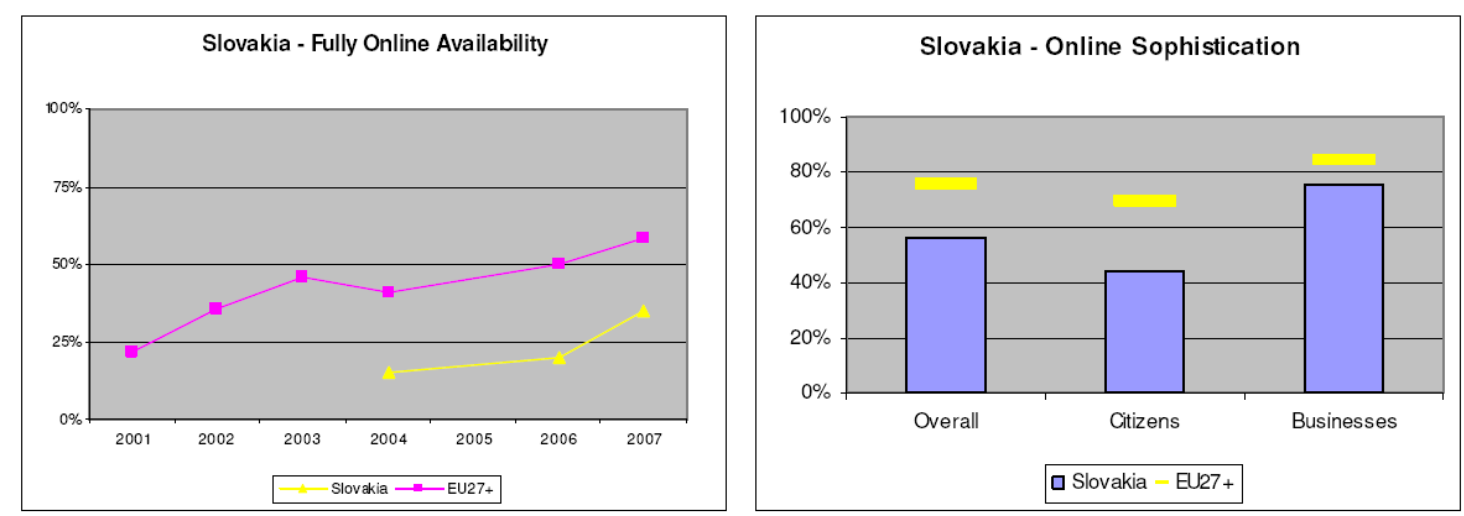

Obr. 6. Online dostupnost' a sofistikácia služieb Slovenska v porovnaní s EU27+ [1]

Slovensko dosiahlo v sledovanej plnej online dostupnosti služieb 35\%. Je tu zlepšenie o $15 \%$ v porovnaní s rokom 2006. $63 \%$ obchodných služieb je plne transakčné, ale len $17 \%$ sú plne online pre občanov.

Online sofistikovanost' Slovenských verejných služieb dosiahla 57\%. Rozdiel medzi sofistikáciou služieb pre občanov a podnikatel’ov je značný. Slovensko zostáva v poslednej štvrtine krajín EU27+.

$\mathrm{Na}$ druhej strane, pri hodnotení národného portálu dosahuje Slovensko dobré výsledky: viac ako polovica verejných služieb je dostupná cez portál. Použitel'nost' a prispôsobenie stránky je taktiež vel'mi dobré (http://www.portal.gov.sk). Slovenský národný portál dosiahol skóre $83 \%$ oproti priemeru EU27+ ktoré je $75 \%$

\section{Česká republika}
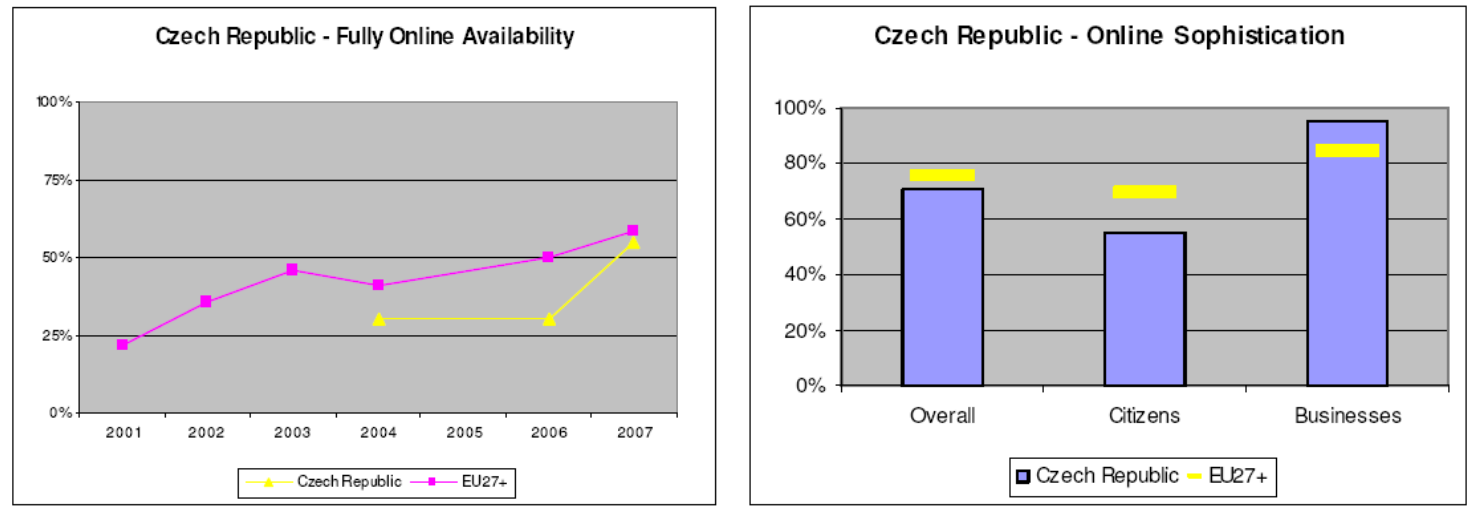

Obr. 7. Online dostupnost' a sofistikácia služieb v Českej republike v porovnaní s EU27+ [1]

Česká Republika spravila významný skok z posledných pozícií v plnej online dostupnosti služieb v roku 2006 na 55\% v roku 2007. Podobný vývoj bol zaznamenaný aj v službách pre podnikatel'ov. Onlie sofistikácia v Českej Republike dosiahla po zavedení nových metód hodnotu $71 \%$.

Hodnotenie národného portálu (http://portal.gov.cz) je ocenené vysoko a to až $98 \%$, pričom priemer EU27+ je 75\%. Väčšina so služieb pre verejnost' je prístupných prostredníctvom tohto národného portálu 


\section{Mad'arsko}
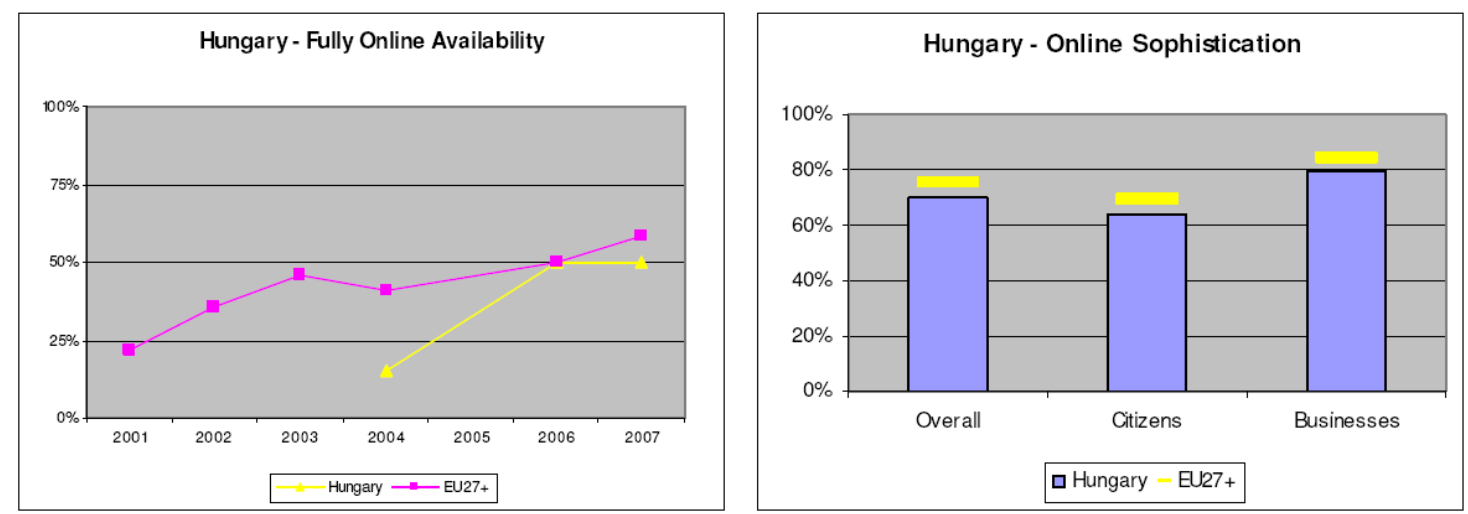

Obr. 8. Online dostupnost' a sofistikácia služieb v Mad’arsku v porovnaní s EU27+ [1]

Dostupnost' online služieb v Mad’arsku je na úrovni 50\% čo je o $8 \%$ menej, ako je priemer EU27+. Sofistikovanost' služieb je v roku 2007 na úrovni 70\%. Národný portál (http://magyarorszag.hu) poskytuje dobrý vstup k online službám v Mad'arsku a bol ohodnotený $77 \%$ čo je nad priemerom EU27+ .

\section{Pol'sko}
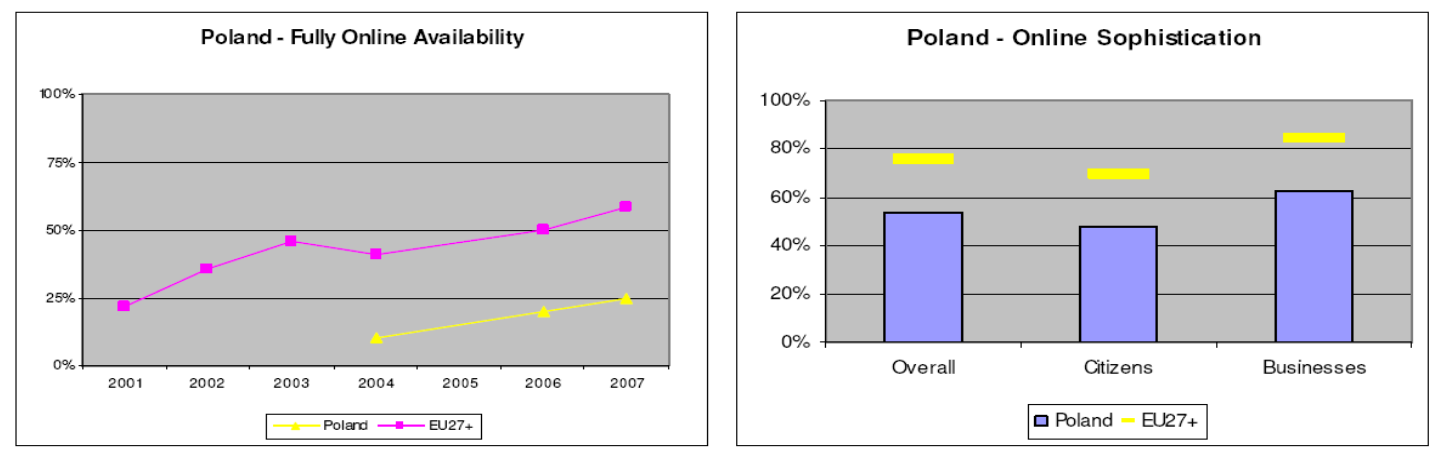

Obr. 9. Online dostupnost’ a sofistikácia služieb v Pol'sku v porovnaní s EU27+ [1]

Online dostupnost' služieb v Pol'sku vzrástla z 20\% v roku 2006 na 25\% v roku 2007. Je tu badatel'ný nárast, ale napriek tomu Pol'sko ostáva v poslednej štvrtine hodnotených krajín. Hodnotenie sofistikácie je na úrovni $53 \%$ čo je pod priemerom EU27+. Služby pre podnikanie sú na tom o čosi lepšie a dosiahli hodnotenie $62 \%$.

Národný portál (http://poland.gov.pl) má prehladné spracovanie s oddeleným prístupom informácií pre občanov hl'adajúcich informácie, zahraničných návštevníkov a informácie o pre podnikatel'ov, o podnikaní.

\section{Slovinsko}

Až 90\% základných verejných služieb v Slovinsku je plne online dostupných a je tu badatel'ný vel'ký rast oproti roku 2006 a tento rast pokračuje d'alej. Slovinsko sa dostalo na štvrté miesto v tomto rebríčku. Online sofistikácia verejného sektora dosiahla $96 \%$. Väčšina verejných služieb je dostupných prostredníctvom národného portálu. Národný portál (http://euprava.gov.si/e-uprava/) je najlepší príklad personalizovanej, cielenej brány pre služby občanom. Slovinsko dosiahlo za ich národný portál hodnotenie $93 \%$, pričom priemer EU27+ je $75 \%$. 

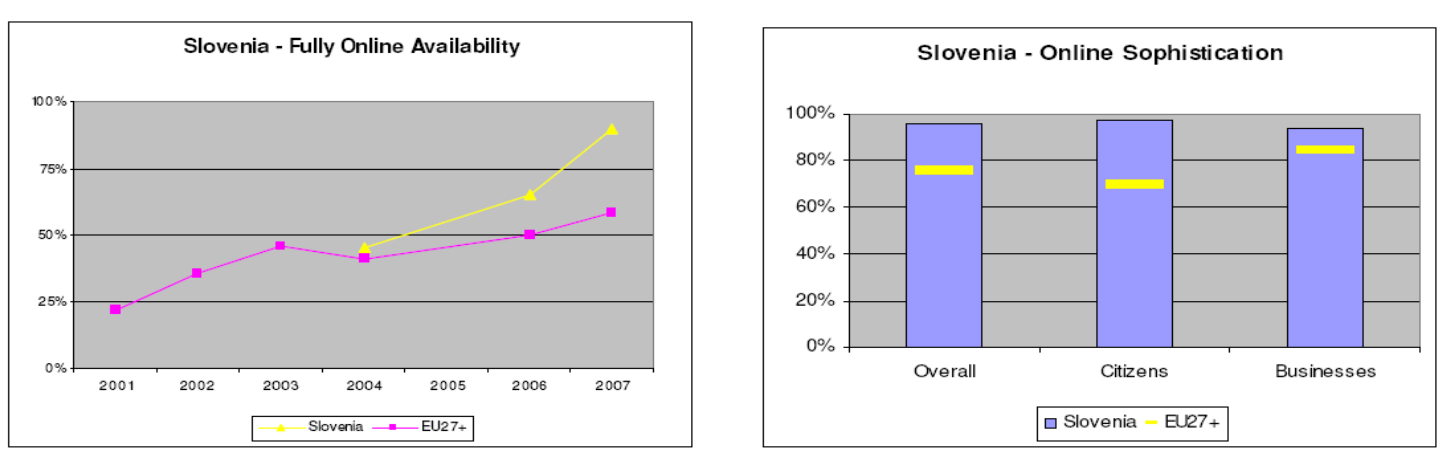

Obr. 10. Online dostupnost' a sofistikácia služieb v Slovinsku v porovnaní s EU27+[1]

\section{Záver}

Hlavnou úlohou e-Governmentu je poskytovat' služby verejnej správy občanom a podnikatel'ským subjektom rýchlo, bez časových obmedzení a prostredníctvom moderných informačných technológií. Úroveň e-Governmentu v jednotlivých štátoch EÚ je rozdielna. Do informatizácie verejnej správy sa investujú nemalé finančné prostriedky, ktoré však ešte stále nie sú postačujúce.

\section{Literatúra}

[1] The User Challenge Benchmarking The Supply Of Online Public Services [Online]. [s.a.].[Citované 2008-12-1] Dostupné na:

http://ec.europa.eu/information_society/eeurope/i2010/docs/benchmarking/egov_benchm ark_2007.pdf

[2] Velešic, M. 2007. e-Government na Slovensku - opät' nový štart? [Online]. [s.a.].[Citované 2008-12-1] Dostupné na:

http://www.ivo.sk/buxus/docs/publicistika/subor/eGovernment Infoware.pdf)

[3] Holka, R.: e-Government v SR, diplomová práca, Katedra spojov, 2008

\section{Grantová podpora}

- VEGA 1/0468/08 Inovačné stratégie v sektore služieb 